every promising method of attack to throw light on the nature and origin of these penetrating radiations and the effects arising in their transmission through matter. The magnitude of the effects to be observed is small and not easy to measure with accuracy; but with the everincreasing delicacy of methods of attack we may hope to gain much further information. The study of these extraordinarily penetrating radia- tions is not only of great interest in itself, but also for its promise of throwing new light on fundamental processes in our universe connected with the building up and destruction of atoms. It may take many years of faithful experiment before the evidence is sufficient to test the correctness of the numerous interesting speculations that have been advanced to account for the origin and nature of these radiations.

\title{
Copper in Antiquity.
}

$\mathrm{O}^{\mathrm{N}}$ $\mathbf{N}$ more than one occasion attention has been directed to the work of the British Association Research Committee which is investigating the sources of Early Sumerian copper. The interim report which was presented at the recent Glasgow meeting of the Association is of exceptional interest. It embodies a report by Prof. C. H. Desch which would appear to point to a possible source from which copper reached Mesopotamia in early times. It is scarcely necessary to say that the quantity of copper and bronze objects found is one of the not least remarkable features of recent excavations on early sites in Sumeria. It has almost revolutionised our conception of the early stages in the growth of civilisation.

The method followed by the Committee has been to analyse chemically as many samples of ancient copper and bronze objects as could be obtained for comparison with the analyses of ores from the various areas in which supplies of copper might have been accessible to the Sumerians. Examples of early date from areas other than Sumeria have also been analysed for purposes of comparison. In the present report, for example, Prof. Desch deals with objects from Susa, Ur, Kish, Bahrein Island, Egypt, including the sheet metal of the statue of Pepy I, now in the Cairo Museum, and North Arcot, India. Specimens from MohenjoDaro are still under examination, and samples from other localities still await attention. Egyptian fragments from various sites supplied by the Ashmolean Museum, Oxford, too small for analysis, were examined spectroscopically. Ores were obtained from Anatolia, Persia, Arabia, and Egypt. Prof. C. O. Bannister, as well as Prof. Desch, has taken part in the work of analysis.

An analysis of three specimens of bronze from the first grave at Ur, dated about 3500 B.c., showed that notwithstanding their early date, they consisted of a tin bronze, with nickel as a characteristic impurity. The figures were as follows :-

\begin{tabular}{|c|c|c|c|c|c|c|}
\hline & & & & $\underset{\text { per cent. }}{A}$ & $\begin{array}{c}\text { B } \\
\text { per cent. }\end{array}$ & $\stackrel{\mathrm{C}}{\text { per cent. }}$ \\
\hline Copper & . & . & . & $84 \cdot 18$ & $85 \cdot 13$ & 85.01 \\
\hline Tin. & . & . & . & 12.00 & $11 \cdot 78$ & $14 \cdot 52$ \\
\hline Lead & . & . & • & 1.62 & $1 \cdot 13$ & 0.47 \\
\hline Nickel & . & . & . & $2 \cdot 20$ & $0 \cdot 25$ & trace \\
\hline Iron & . & . & . & - & $1 \cdot 71$ & - \\
\hline
\end{tabular}

No. 3084 , VoL. 122]
Specimens obtained from the excavations at Kish in 1928 also contained nickel, though in smaller quantities, while of specimens obtained in 1925 , copper from. Mound A (3000 B.c.) showed nickel $3 \cdot 34$ per cent, and bronze from Mound W (Nebuchadnezzar) showed of nickel a trace, with $4 \cdot 65$ of tin and $6 \cdot 16$ of iron. Samples from Tel-el-Obeid showed respectively nickel 0.12 (from the frieze) and 0.23 (a nail) ; but a nail from Iraq of 2000 B.c. yielded no nickel.

In no case was there antimony.

Bronze dated with some probability at 1200 B.C. obtained by Sir Flinders Petrie from tumuli in Bahrein Island, yielded nickel in two cases in a percentage of 0.27 and 0.52 . These specimens in the quantity of sulphur present showed evidence of imperfect smelting, while the proportion of tin present in some was so high as to render the bronze too brittle.

Among the Egyptian samples, the sheet metal from the statue of Pepy showed a remarkably high percentage of nickel-1.06. The Egyptian specimens examined spectroscopically showed no traces of gold or nickel. Some were pure copper ; others showed traces of iron and arsenic, with, in one case, tin $5 \cdot 25$ per cent. The North Arcot specimens had 0.25 per cent of nickel.

Prof. Desch quotes analyses of three objects by Von Bibra from the North-West Palace of Nineveh found by Layard, containing $0 \cdot 18,0 \cdot 30$, and $0 \cdot 20$ per cent of nickel respectively, while J. Sibelien found 0.28 per cent of nickel in a Sumerian statuette (about 3000 B.C.) and 0.43 per cent in a copper adze of the First Egyptian Dynasty.

Having these results in view, and having regard to the fact that nickel is by no means an invariable constituent in copper ores, the aim of the Committee is now to find an ore which would be likely to yield nickel in such proportions. Native copper from Angora has yielded copper $99 \cdot 83$, a trace only of tin, $\mathbf{0} \cdot 17$ of iron, and no trace of nickel, while native copper from Arghana with 97.08 of copper, 0.27 of tin, $2 \cdot 13$ of iron, has 0.03 of nickel. A copper chisel of the early dynastic period yielded copper $93 \cdot 21$ per cent, silver $2 \cdot 51$ per cent, gold $4 \cdot 14$ per cent, lead 0.05 , and arsenic 0.06 per cent, and was therefore prcbably composed of native metal.

Ores from Persia, the Black Sea, and the Sea of Marmora, Cyprus, various parts of Egypt and Sinai, yielded no result, all being free from nickel. 
Recently, however, an ore was found, accompanied by slag, at Jabal al Ma'adan in Wadi Ahin, inland from Sohar, in the State of Oman, which proved to contain nickel. It was found only in the form of thin veins, much mixed with other minerals. The percentage of copper was small, but that of nickel relatively to the copper was very high. The figures were copper $1 \cdot 0$, nickel $0 \cdot 19$. The slags contained 1.50 and 4.30 per cent of copper and no nickel, which is in accordance with probable smelting practice.

The Committee has thus achieved a tangible and encouraging result, though it would be going beyond the evidence at the moment to suggest that it is conclusive. Mr. H. Peake, however, in a communication presented to the recent Orientalist Congress at Oxford, suggested that Jabal al Ma'adan might be the site of Magan, referred to by Sargon in his geographical tablet and mentioned in the time of Judea in the lists as one of the places from which came ships and copper.

On the other hand, Prof. Desch mentions an ancient bronze object from the Transvaal which contains so much as 3 per cent of nickel. $\mathrm{He}$ thinks that as the copper ore, which is malachite in a quartz gangue, is accompanied by a green nickel arsenate, anabergite, this might have been mistaken for malachite, thus explaining the presence of nickel. This is suggestive, for it is known that farther to the north in the Belgian area nickel blooms have been used. Although vast quantities of metal have been taken from the Transvaal and Katanga area, the age of these workings is quite unknown. It certainly should be investigated. Another research committee of the British Association has this question under consideration, but is unable to continue its investigations owing to lack of adequate funds.

\section{Obituary.}

Prof. R. A. Berry.

$\mathrm{T}$ HE sudden death of Reginald Arthur Berry, which took place in Glasgow on Oct. 12, at the early age of fifty-two years, deprives Scotland of one of its most active workers in agricultural science. Berry was educated at Oundle and at Cambridge. After acting as assistant for several years to the late Prof. Liveing, he transferred in 1900 to the School of Agriculture at Cambridge. There he worked with Prof. T. B. Wood for the next five years, and, in collaboration with him, published some valuable papers ; in particular their investigation into the composition of root crops has always been regarded as a fundamental piece of work.

In 1905, Berry was appointed professor of agricultural chemistry in the West of Scotland College of Agriculture at Glasgow. Here his teaching duties were heavy, and his laboratory accommodation meagre and inconvenient; notwithstanding these difficulties he steadily carried on his work, and the large number of papers published during the last twenty-three years bears evidence to his zeal and to his wide interest in the various divisions of agricultural chemistry. An investigation into the composition of oats was followed by a large number of papers dealing with feeding problems and with various aspects of dairying; he did much work on the utilisation of the by-products of the dairy industry, and, at the last meeting of the British Association in Glasgow, presented, in conjunction with Mr. A. Macneilage, the results of an inquiry of much economic importance into the utilisation of surplus milk. Berry was also much interested and took a share in the development of the modern methods of soil surveying which have been adopted in Great Britain ; he was an active member of the Scientific Advisory Committee to the Royal and Ancient Golf Club.

Berry married the elder daughter of the late Mr. James Smith, of Doonfoot, Ayrshire, and is survived by his widow and two daughters. He had a wide circle of friends, by whom his memory will ever be held in affectionate remembrance.
Mr. S. R. Pike.

The death occurred on Nov. 22, in hospital at Pasadena, California, of Sydney Royston Pike. Mr. Pike was born in 1903, and showed a marked bent towards astronomy from early years. He entered Balliol from Bedford School in 1920 with a scholarship awarded for distinction in that subject. Graduating with a first class in physics in 1924, and following this up by a year's research in Oxford, he was appointed assistant lecturer in physics in the University of Leeds in 1925, and soon showed his originality by a series of papers on astrophysical subjects. During the present year, having been awarded a research fellowship by the International Education Board, and granted a year's leave of absence by the University, he proceeded to Mt. Wilson in September, and had scarcely begun work when symptoms of meningitis, following a severe chill, necessitated his removal to hospital.

In letters Mr. Pike had remarked on the universal kindness with which he had been received by his new friends in California. To all of them his relatives and English colleagues wish to express their deepest gratitude. They also wish to record their high appreciation of the generous action of the American authorities under whose auspices Mr. Pike was working, in according him a last resting-place near the great observatory in which his labours were so prematurely cut short.

WE regret to announce the following deaths:

Prof. T. C. Chamberlin, emeritus professor of geology in the University of Chicago, the Nestor of American geologists, who was a foreign member of the Geological Society of London, on Nov. 15, aged eightyfive years.

Dr. V. E. Emmel, professor of anatomy in the college of medicine of the University of Illinois, on Nov, 8, aged fifty years.

Prof. Franz Stuhlmann, formerly general secretary of the Hamburg Colonial Institute and one of the pioneers in the opening-up of German East Africa, who accompanied Emin Pasha in his last expedition in 1894 , aged sixty-five years.

$$
\text { No. 3084, VoL. 122] }
$$

